\title{
TITLE: Notes on the RF System for the SLC Positron Source.
}

\section{General Layout of the RF System.}

The proposed arrangement.of accelerator structures, waveguide feeds and klystrons is sketched in Fig. 1.

A $50 \mathrm{MW}$ klystron at 20-3C will provide power for the high-field ca' "ure section immedintely following the target. About 1 meter downstream of this secti : there will be a standard girder of four 3.05-meter SLAC constant gradient acceleral : sections. Tbese will be powered by a klystlon at station 20-3D. Current thinking is that this will also be a $50 \mathrm{MW}$ tube, but $35 \mathrm{MW}$ might well be sufficient. Both statir $\&$ will he SLEDded.

The length of the rectangular waveguide feed to the capture section will be approximately $132 \mathrm{ft}$, and the attenuation will be about $0.87 \mathrm{db}$. The corresponding numbers for the feed to the standard girder are $153 \mathrm{ft}$ and $1.07 \mathrm{db}$.

\section{The High-Field Capture Section.}

In CN-268 dated 6/22/84: "Positron Source: First 50 Nanoseconds," K. A fieit shows that good positron acceptance requires very high accelerating fields lon the der of $70 \mathrm{MV} / \mathrm{m})$ in the first meter following the target. Various ways of appronching this gradient in a 1 -meter section have been examined.

The alternatives considered are all 29-cavity structures (total length $1.015 \mathrm{~m}$ ) operating in the $2 \pi / 3$ mode at $2856 \mathrm{MHz}$. All expressions used are taken from Chapter B.1.1, "Accelerating Structures," by G. A. Loew and R. B. Neal, in "Linear Accelerators" edited by P. M. Lapostolle and A. L. Septier, North Holland, 1970.

Cases considered are as follows:

$$
\begin{gathered}
\text { Traveling Wave }=\mathrm{TW} \text {, Standing Wave }=\mathrm{SW} \text {, } \\
\text { Recirculating }=\text { Rec, Constant Gradiest }=\mathrm{CG} \text {, } \\
\text { and Constant Impedance }=\mathrm{Cl}
\end{gathered}
$$
1) First 29 cavities of SIAC CG structure
TW
2) First 20 cavities of SLAC CG structure
Rec
3) Last 29 cavities of SLAC CG struclure
TW
4)
Last 29 cavities of SLAC CG structure
5)
6)
7)
29 Cl cavities like cavity 1 of SLAC CG structure
TW
SW
Rec

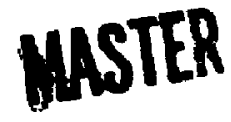

\footnotetext{
"Work supported the Department of Energy, Contract DE-AC03-76SF00515.
} 
9) 28 CI cavities like cavity 21 of SLAC CG st.ructure

Parameters are tabulated below:

PARAMETERS EOR SOME 1.015-METER CAPTURE SECTIONS

\begin{tabular}{|c|c|c|c|c|c|c|c|}
\hline \multirow{4}{*}{$\begin{array}{l}\text { Disk } \\
\text { Aperture } \\
\text { Diameter (mm) }\end{array}$} & \multicolumn{3}{|c|}{$\begin{array}{l}\text { Constant } \\
\text { Gradient }\end{array}$} & \multicolumn{3}{|c|}{$\begin{array}{l}\text { Constant } \\
\text { Impedance }\end{array}$} & \multirow{3}{*}{19.24} \\
\hline & $\overline{26} . \overline{22}$ & 22.22 & & & & & \\
\hline & to & to & 26.22 & $25.5 \mathrm{C}$ & 23.49 & 21.66 & \\
\hline & 24.46 & 19.24 & & & & & \\
\hline & $.020 \overline{2}$ & $. 0 \longdiv { 1 1 }$ & & & & & \\
\hline$v_{g} / c$ & $\begin{array}{c}\text { to } \\
.0165\end{array}$ & $\begin{array}{l}\text { to } \\
.0065\end{array}$ & .0202 & .0168 & .0134 & .0019 & .0065 \\
\hline-- & 53.0 & 57.7 & & & & & \\
\hline$R_{0} \mathrm{M} \Omega / \mathrm{m}$ & to & to & 53.0 & 54.75 & 56.5 & 58.25 & 60.0 \\
\hline 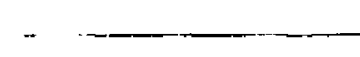 & 55.3 & 60.0 & & & & & \\
\hline$Q$ & io & to & 14200 & 13950 & 13700 & 13450 & 13200 \\
\hline & 13870 & 13200 & & & & & \\
\hline$\alpha$ (nepers) & $\begin{array}{l}.104 \\
10 \\
.138\end{array}$ & $\begin{array}{l}.185 \\
\text { to } \\
.349\end{array}$ & .104 & .128 & .182 & .225 & .348 \\
\hline $\begin{array}{l}T \text { (nepers) } \\
\text { (dI3) }\end{array}$ & $\begin{array}{l}.118 \\
1.03\end{array}$ & $\begin{array}{l}.258 \\
2.25\end{array}$ & $\begin{array}{l}.106 \\
.819\end{array}$ & $\begin{array}{l}.130 \\
1.13\end{array}$ & $\begin{array}{l}165 \\
1.44\end{array}$ & $\begin{array}{l}.228 \\
1.88\end{array}$ & $\begin{array}{l}.35 .1 \\
3.08\end{array}$ \\
\hline Filling time $T_{f} T^{n}$ & $\overline{188}$ & $38 \overline{9}$ & 188 & 201 & 253 & 342 & 520 \\
\hline $\begin{array}{l}\text { SĩliD Acceleratu: } \\
\text { Voltage } \\
\text { Gain Factor }\end{array}$ & 2.38 & 2.19 & 2.40 & 2.38 & 2.33 & 226 & 2.11 \\
\hline $\begin{array}{l}\text { SLED RF } \\
\text { Power Gain } \\
\text { Factor }\end{array}$ & 6.47 & 6.40 & 6.48 & 6.4i & 6.45 & 6.42 & 6.35 \\
\hline $\begin{array}{l}\text { Non-SLED Energy (MeV) } \\
35 \mathrm{MW} \text { klystron } \\
\text { (28MW into Section) }\end{array}$ & 18.1 & 26.0 & 17.0 & 18.9 & 21.2 & 24.6 & 29.3 \\
\hline
\end{tabular}


PARAMETERS FOR SOME 1.015-METER

CAPTURE SECTIONS (Continued)

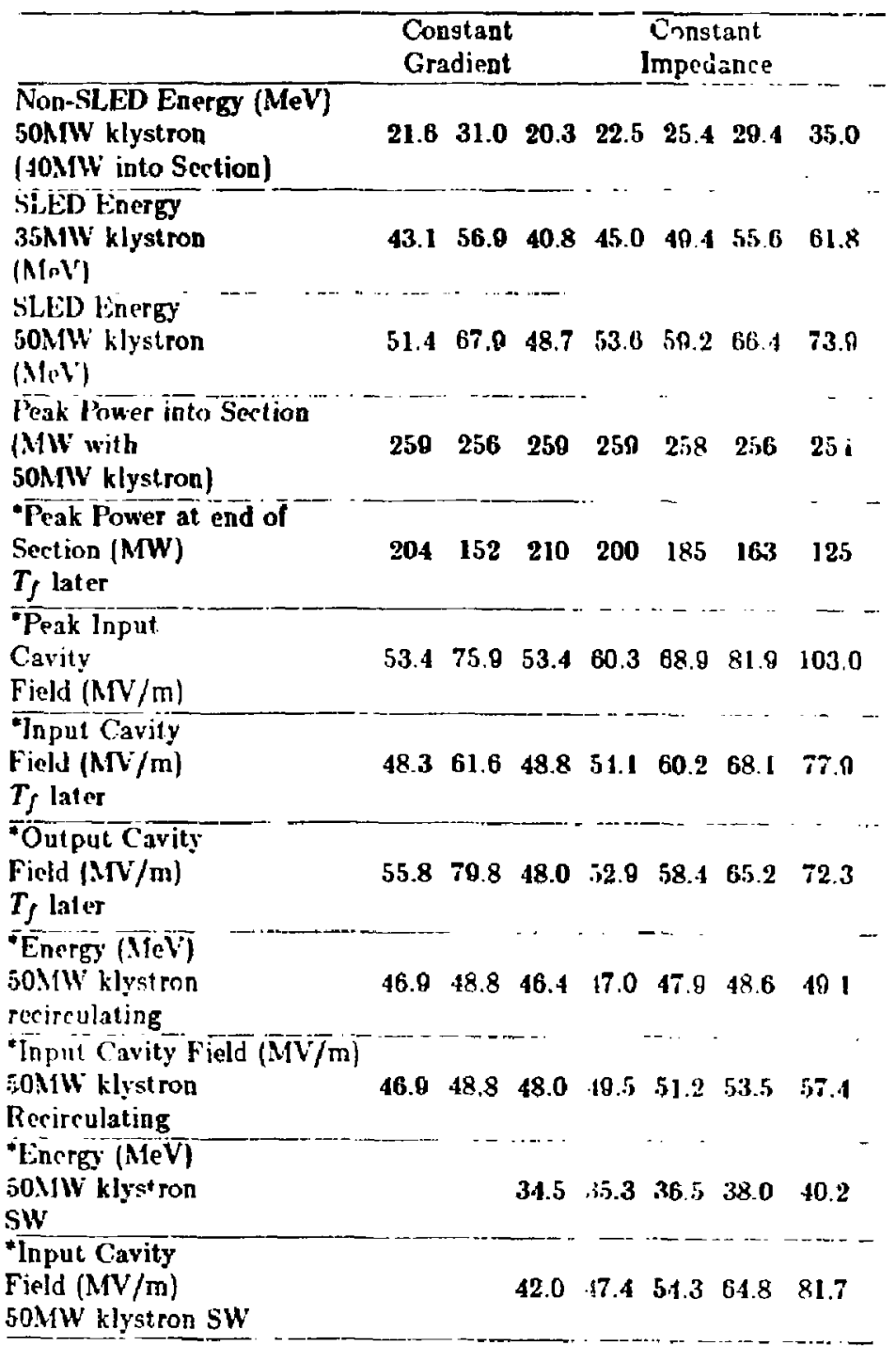

*50 MW klystron 
Some fields and energies are plotted in Fig.?.

It turas out that the highest gradient structure (Cl with cavity dimensions equal to the last cavity of the SLAC $3.05 \mathrm{~m}$ section) is also the easiest and quickest to design and build. Obviously, both couplers would be the same as the SLAC output coupler. However, as wake-feld effects are a strong iarerse function of the iris aperture diameter, it might be prudent to choose a slightly larger diameter, such as $21.66 \mathrm{~mm}$. This reduces the " $i$ ing time and the input cavity paak feld, and requires a modified coupler design.

Standing-wave structures, either uniform or triperiodic, do nol secm advantagcous.

\title{
3. The Standard (CG) Girder.
}

The rnergy contribution of the four CG DLWG sections, fed in parallel by one S1,EDded $50 \mathrm{MW}$ klystron, will be $240 \mathrm{MeV}$. If a $35 \mathrm{MW}$ tube were used, the energy would be $200 \mathrm{MeV}$.

\section{Special Drive Requirements for 20-3C and 20-3D.}

It is certain that klystron $20-3 \mathrm{C}$, driving the rapture section, will need a drive system independeat of Sector 20 Sub Booster. In order to achieve maximum energy gain, the peak SLED ficld must enter the section one filling time before the beam. The solested filling time will be betwern $168 \mathrm{~ns}$ and $520 \mathrm{~ns}$, compared to $830 \mathrm{~ns}$ for the standard sections in Sector 20. Also, the rectangular waveguide group delay will be about $98 \mathrm{~ns}$ longer than it is in the standard configuration. Additionally, separate phase and amplitude controls will be necessary. Thus a separate Solid-State Sub-Bouster (SSSB) with its own phase-shifter, attenuator and PSK switch will be required.

The beam arrival time at the four CG sections would be about 60 ns belore the end of the RF pulse, if the Sector 20 drive were used for 20-3D. This would lower the energy by about 7\%, which might be acceptable. However, separate phase and amplitude controls will be desirable, so another SSSB is the preferred solution.

\section{DISCLAIMER}

\begin{abstract}
This report was prepared as an account of work sponsoned by an agency of the United States Government. Neither the Linited States Government nor any agency thereof, mor any of their employes, makes any warranty. express or implied, or assumes any iegal liability or responsi bility for the securesy, completeness, or usefulness of any information, apparstus, producl, of process disclosed, or represents that its use would not infringe privately owned rights. Reference herein to any specific commercial product, process, or service by trade name, trademark. manufacturer, nr otherwise dres not necessarily constitule or imply its endorsement, renommendation, or favoring by the United States Government or any agency therear. The views and opinions of authors expressed herein do rot necessarily state or reflect those of the United Stoles Government of any agency thereof.
\end{abstract}




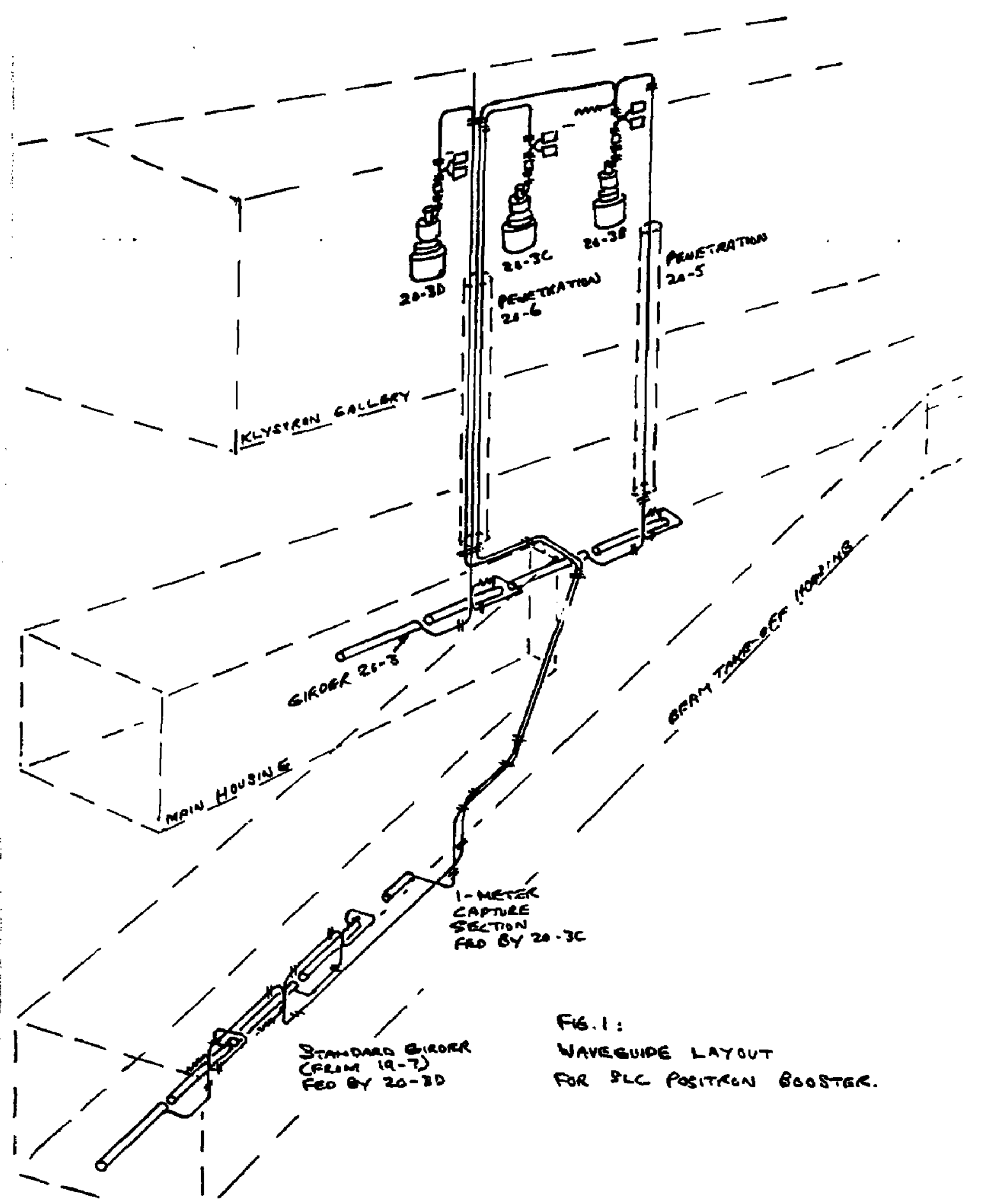




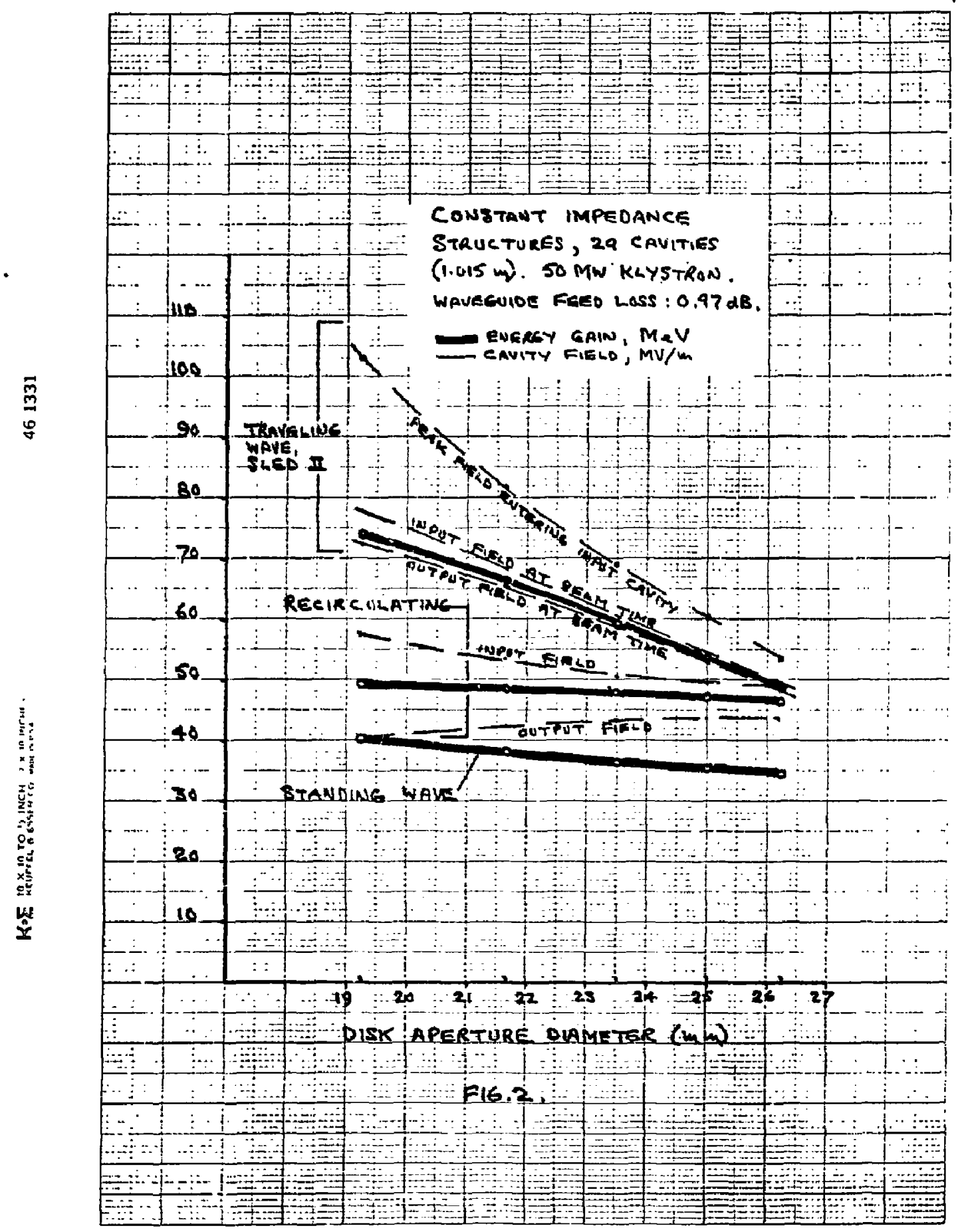

